Misr J. Ag. Eng., 26(1): 485- 497

BIOLOGICAL ENGINEERING

\title{
TECHNICAL AND ECONOMICAL STUDY FOR COMPOSTING AERATION UNDER EGYPTIAN CONDITIONS
}

\author{
*E. H. Ewida, **M. N. El Awady, ***O. M. Kamel, \\ ***** M. A. Geneady, ${ }^{* * * * * *}$ M. El-Berdiney
}

\begin{abstract}
Livestock manure, amended with rice straw, was composted by: natural aeration (NA), passive aeration with corn stalks (PA), and agitation (Agi). For each method, one composting pile was built and monitored from Feb. to Aug. 2007. The compost piles had initial volume of $4.5 \mathrm{~m}^{3}$ and $1.5 \mathrm{~m}$ height. Temperature profiles of replicated positions showed a high degree of similarity suggesting that the raw compost was uniform and the process was reproducible. The results showed that for the selected configuration of aeration and agitation schedule. PA(1) had a higher process rate than NA, (2) provided adequate oxygen without the adverse effect of cooling as observed in the case of Agi, (3) maintained high temperatures for a longer maturation than the other two methods, (4) the final properties of compost were different in C/N, pH, EC, N, P, K, O.C, $O . M$ from other treatments. Generally the results showed that using any of these compost treatments produced good quality compost, but both of $P A$ and NA are less expensive than Agi.
\end{abstract}

Keywords: passive aeration, natural aeration, agitation, manure composting, open composting systems.

\section{INTRODUCTION:}

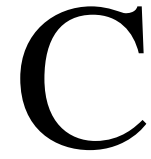
omposting is not that popular in Egypt, and this may be due to many reasons, such as high expenses of turning machines mostly used in Egypt, or the Egyptian farmers prefer using animal manure instead of compost - after the spread of bird flu in Egypt using

\footnotetext{
* Master student in Ag. Eng., Ain-Shams Univ.

**Prof. Emt. of Ag. Eng., Ain-Shams Univ.

***Peputy Min, MOALR. ****Assoc. Prof. of Ag. Eng, Ain-Shams Univ. *****Assoc. Prof. of Soil Science, Col. Ag.,Ain-Shams Univ.
} 
chicken manure. Even using of livestock manure is not safe either. Researchers have not made this technology adequately available to the farmer in the Egyptian conditions.

Composting is a viable waste management alternative for manure slurries. By confining the waste to a single location and optimizing process variables, a high rate aerobic decomposition can take place with minimal volatile emanations (Sartaj et al., 1997).

Composting, as described by (Haug, 1993), is a biological decomposition and stabilization of organic substrates under condition that allows development of thermophilic temperatures, as a result of biologically produced heat, to produce a final product that is stable, free of pathogens and plant seeds, and can be beneficially applied to land.

In order for the microorganisms to thrive and be most efficient in their work, they must be provided with a suitable nutrient, water, and oxygen supply, as well as environment in which thermophilic temperatures (greater than $40^{\circ} \mathrm{C}$ ) can be maintained. The temperature and moisture and air contents of compost are physical properties in themselves, but each of these requirements are influenced by other physical properties of composting materials (Agnew and Leonard, 2003).

(Seki, 2002) stated that composting systems dispose and recycle organic solid wastes, and represent one of the elementary techniques for realizations of society's aim to reuse and recycle, and described composting mass as a multi-component, multi-phase, heterogeneous system.

(Rynke, 1992) described composting as a biological process in which microorganisms convert organic materials such as manure, sludge, leaves, paper, and food wastes into a soil-like material called compost, and also defined composting as an aerobic decomposition of organic materials under controlled conditions. During composting, the microorganisms consume oxygen while feeding on organic matter. Active composting generates considerable heat, large quantities of carbon dioxide and water vapor are released into air. Composting thus reduces both the volume and mass of the raw materials while transforming them into a valuable soil conditioner. 
This study tries to determine the best method to compost the agricultural wastes under Egyptian conditions. The experiment was established in a village at Rasheed city (مدينة رشيد) at the north coast in Egypt beginning at the winter. These conditions were chosen to achieve the worst weather conditions for the open composting systems.

\section{MATERIALS AND METHODS:}

The experiment started on the $7^{\text {th }}$ of February 2007 and ended after 177 days on the $2^{\text {nd }}$ of August 2007. It was carried out in the "Central Laboratory of Agricultural Climate (CLAC) Farm" مزرعة المعل المركزي) (للمناخ - مركز البحوث الزراعية), Agriculture Research Center (ARC), Ministry of Agriculture at El-Bossily village, Rasheed, El-Behera governorate ( قرية (البوصيلي - مدينة رشيد - محافظة البحيرة.

The raw material used in this experiment was water-buffalo manure as waste, and rice straw was used as animal bedding. The rice straw was considered as the bulking agent. Manure was obtained from a farm near the experimental farm. Raw and final material properties are included in table 1 (Central Lab, Col. Ag, A. Shams U.)

Table 1. Properties of initial and final materials

\begin{tabular}{|l|l|l|l|l|}
\hline Property & Raw Materials & Pile Agi Final & Pile PA Final & Pile NA Final \\
\hline $\begin{array}{l}\text { Moisture of } \\
\text { Content } \%\end{array}$ & 32.60 & ----- & ----- & ---- \\
\hline $\mathrm{pH}$ & 9.00 & 8.27 & 8.67 & 8.69 \\
\hline Ec (ds/m) & 8.89 & 6.34 & 6.33 & 7.05 \\
\hline $\mathrm{K} \%$ & 0.29 & 1.32 & 1.32 & 1.35 \\
\hline $\mathrm{P} \%$ & 0.44 & 0.61 & 0.58 & 0.58 \\
\hline $\mathrm{N} \%$ & 1.66 & 0.63 & 0.69 & 0.7 \\
\hline O.C \% & 24.24 & 11.77 & 10.69 & 10.57 \\
\hline C/N \% & 14.97 & 18.47 & 15.67 & 15.1 \\
\hline O.M \% & 41.79 & 20.27 & 18.4 & 18.2 \\
\hline
\end{tabular}

NOTE: Reported value for raw material is the average of 4 measurements, and the values for the final products are averages of three measurements for each pile.

Three composting systems (Passively aerated, naturally aerated, and agitated) were examined. Three piles were constructed by front-end loader and shaped manually by two farmers. The dimensions of each pile 
were $3.5 \times 2 \mathrm{~m}$ at the bottom with $1.5 \mathrm{~m}$ height and $4.5 \mathrm{~m}^{3}$ volume. A $5 \mathrm{~cm}$ thick base of rice straw was laid on the ground surface.

The naturally aerated static pile (NA), fig. 1, was used as a "blank treatment". So it did not use extra agitation or aeration. This treatment is considered as the base of all open composting systems according to (Haug, 1993). Aeration depends on natural convection inside the composting piles. Hot air in the core of the pile rises up and replaces cold air by convection.

Advantages of this method are:

1. Simplicity.

2. Does not require skillful labor.

3. Does not involve agitation.

In spite of the above advantages, the method is not popular in Egypt, because of its law efficiency and time consuming.

The passively aerated static pile (PA), fig. 2, was developed to suit the Egyptian conditions by replacing PVC perforated pipes by bundles of corn stalks for simplicity. This system depends on helping the movement of natural convection of air inside the composting pile to its core. This solution might be considered the best for small and medium scale farming, and also for manure piles as explained by (Sartaj et al., 1997). Three pairs of corn-stalk bundles were put in the composting pile with a $0.75 \mathrm{~m}$ height from the ground. The first pair was put in the center of the pile, one in the east and another in the west side. The distance between each pair is one meter. The corn-stalk bundle consisted of 10 stalks wrapped together with 2 meter length. Three rows were used in the passively aerated pile. Every row consisted of two wraps of corn-stalk. There was intersection between each pair of bundles in the same raw to make an air conduit in the pile to help convection and air movement within the pile. The corn-stalk bundles were overlapped in the core to insure maximum aeration efficiency by making air conduits.

The Agitation pile (Agi), fig. 1, is the most popular composting methods in Egypt, and is almost the only one used in producing compost for commercially. This method suits the warmness and the dryness of the Egyptian climate, which makes Egypt a very good environment for all open composting methods. It is considered very expensive for small-scale 
composting. The agitation process was scheduled twice a month after forty days of the pile age, not depending on the temperature measurements as it should be, because the temperature instruments are not available to the farmer. The period of the first forty days was without turning because of the rain and cold weather which may be shortened in the summer.

Temperatures were measured by compost digital thermometer that uses a K-type sensor (HI 935005). The probe was one-meter long and one centimeter diameter stainless steel (HI 766TR2). The probe measures temperatures up to about $200 \mathrm{C}^{\circ}$. The response time of the thermometer (for $90 \%$ of final value) was 10 seconds. The instrument is made by HANNA Instruments Co. (HANNA Website, 2008).

Front-end loader was used for turning the pile with the aid of two assistants to reshape it to the dimensions above. The time of turning depends on the volume of the pile, the capacity of the loader, and the driver skill. The $60 \mathrm{~kW}$ loader was made in Holland by Fiat Co.

- Machine expenses were estimated by the following formula:

$$
\mathrm{C}=\mathrm{p} / \mathrm{h} \times(1 / \mathrm{y}+\mathrm{i} / 2+\mathrm{t}+\mathrm{m})+(\mathrm{a} \times \mathrm{k} \times \mathrm{f} \times \mathrm{u})+\mathrm{s} / 144
$$

(Awady, 1978)

Where:

c: Total hourly cost (LE/h).

p: Price of machine (200,000LE).

$\mathrm{h}$ : Working hours per year $(1,000 \mathrm{~h}$ for loader $)$.

y: Machine lifetime in years (10yr).

i: Capital investment percentage (0.1).

$\mathrm{t}$ : Taxes and overheads percentage $(0.2)$.

$\mathrm{m}$ : Maintenance (0.05).

a: Oil and lubrication percentage of rated power ( $90 \%$ of fuel uses).

$\mathrm{k}$ : The machine power $(60 \mathrm{~kW})$.

f: Fuel consumption $(0.351 / \mathrm{kW} . \mathrm{h})$.

$\mathrm{u}$ : Price of fuel (1.1LE/l).

s: operator wages (800LE).

(Awady et al., 2006)

The cost to agitate the compost windrow:

$c_{w}=c \times w$ 
Where:

$C_{w}$ : Total cost to agitate the windrow (LE/windrow).

$\mathrm{w}$ : Time needed to agitate windrow $(0.25 \mathrm{~h} /$ windrow $)$.

$\mathrm{c}_{v}=\mathrm{c}_{\mathrm{w}} / v$

Where:

$C_{v}$ : Total cost to agitate the cubic meter $\left(\mathrm{LE} / \mathrm{m}^{3}\right)$.

$\mathrm{v}$ : Volume of the windrow $\left(4.5 \mathrm{~m}^{3}\right)$.

\section{RESULT AND DISCUSSION:}

\section{Temperature:}

During microbial substrate decomposition, energy on the form of heat is released. It affects the composting pile and causes the temperature to rise. This heat generation can be used as an indicator of composting performance. To determine the effect of aeration on temperature performance, all other factors such as $\mathrm{MC}, \mathrm{C} / \mathrm{N}, \mathrm{pH}$, and the availability of organic matter were kept at the same initial level. Then air supply is the factor causing temperature variations in the composting piles. It should be noted that a different agitation schedule or configuration of passively aerated materials (corn stalk) results in a different temperature regime.

\subsection{Temperature difference between layers:}

Results illustrated in figures $3 a, b$, and $c$ show temperature differences between layers in composting piles. They show that the bottom layer had the lowest temperature regime of all composting methods, and that could be improved by the porous bed. After that, comes the middle layer of composting and then the top layer, almost with the highest temperature level.

Figure 3a shows that in the naturally aerated method, the bottom layer had the lowest temperature regime until the end of active phase, though it never reached $40^{\circ} \mathrm{C}$, and the max. temperature was $36.2^{\circ} \mathrm{C}$ on the $22^{\text {nd }}$ day of the experiment. The highest temperature was $38.1^{\circ} \mathrm{C}$. However, the temperature rise was equal for all the layers at the end of curing phase. The middle and top layers were almost equal with higher temperature at the top layer reaching over $40^{\circ} \mathrm{C}\left(42.7^{\circ} \mathrm{C}\right)$ on the $22^{\text {nd }}$ day and the highest degree was $46.8^{\circ} \mathrm{C}$ on the $43^{\text {rd }}$ day of the active phase, the middle layer reached above $40^{\circ} \mathrm{C}\left(41.2^{\circ} \mathrm{C}\right)$ on the $22^{\text {nd }}$ day and the highest degree was $44.1^{\circ} \mathrm{C}$ on the $40^{\text {th }}$ day. However, the middle layer got higher 
temperatures than the top layer in curing phase until all layers become equal at the end.

Figure $3 \mathrm{~b}$ shows that in the passively aerated method, the bottom layer had the lowest temperature regime until the end of active phase though the average never reached $40^{\circ} \mathrm{C}$ and the max. temperature was $39.2^{\circ} \mathrm{C}$ on the $22^{\text {nd }}$ day of the experiment in the active phase. The highest temperature was $44.5^{\circ} \mathrm{C}$, but the temperature rise for the middle layer equaled and exceeded the top layer at the end of curing phase. The middle and the top layers were almost equal with higher temperature at the top layer reaching $40 \mathrm{C}^{\mathrm{O}}$ on the $12^{\text {th }}$ day. The highest temperature average was $48.5^{\circ} \mathrm{C}$ on the $22^{\text {nd }}$ day of the experiment, and the highest temperature measurement was $53.2^{\circ} \mathrm{C}$. The middle layer reached above $40^{\circ} \mathrm{C}\left(45.9^{\circ} \mathrm{C}\right)$ on the $19^{\text {th }}$ day of the experiment. The highest temperature measurement was $50.3^{\circ} \mathrm{C}$. In curing phase, the top layer decreased in temperature to the end of curing phase and the bottom layer increased in temperature to equal the middle layer at the end of curing phase.

Figure $3 \mathrm{c}$ shows that in the agitation method, the bottom layer had the lowest temperature until the end of the active phase. The temperature never exceeded $40^{\circ} \mathrm{C}\left(36^{\circ} \mathrm{C}\right)$ on the $22^{\text {nd }}$ day of the experiment. However the temperature rose in the curing phase to equal the top layer at the end of the phase. The top and the middle layers were almost equal in temperature to the top layer, reaching above $40^{\circ} \mathrm{C}\left(42.1^{\circ} \mathrm{C}\right)$ on the $22^{\text {nd }}$ day and the highest temperature average was $44.3^{\circ} \mathrm{C}$ on the $36^{\text {th }}$ day of the experiment, while the highest temperature measurement was $51.5^{\circ} \mathrm{C}$. The middle layer reached $40^{\circ} \mathrm{C}$ on the $22^{\text {nd }}$ day of the experiment, and the highest average of $43.2^{\circ} \mathrm{C}$ was on the $33^{\text {rd }}$ day, while the max. temperature measurement was $46.5^{\circ} \mathrm{C}$.

\subsection{Temperature differences between composting methods:}

Figure 4 shows the advantage of passively aerated system. In the active phase the temperature reached the temperature of $40.9^{\circ} \mathrm{C}$ on the $19^{\text {th }}$ day and the highest average was $43.5^{\circ} \mathrm{C}$ on the $29^{\text {th }}$ day and the highest temperature measurement was $53.2^{\circ} \mathrm{C}$. For the agitation system in the active phase, the temperature reached $40.6^{\circ} \mathrm{C}$ on the $33^{\text {rd }}$ day. The highest average was $40.9^{\circ} \mathrm{C}$ on the $36^{\text {th }}$ day, and the highest temperature was $51.5^{\circ} \mathrm{C}$. The naturally aerated system had the lowest temperature regime. 
The temperature reached $40^{\circ} \mathrm{C}$ on the $22^{\text {nd }}$ day. the highest temperature average $41.9^{\circ} \mathrm{C}$ on the $43^{\text {rd }}$ day, and the highest temperature measurement was $49.1^{\circ} \mathrm{C}$. In the curing phase, the passively aerated treatment had higher temperature over agitation system by about $5^{\circ} \mathrm{C}$ and over the agitation by more than $5^{\circ} \mathrm{C}$.

\section{Economical Comparison:}

In the agitation composting pile, the front-end loader was used as turning equipment for the pile with cost $(\mathrm{C}=130 \mathrm{LE} / \mathrm{h})$ and based on minimum charge per hour when renting the turning equipment. The pile takes 15 minutes to be turned, so the turning costs for the windrow $\left(\mathrm{C}_{\mathrm{w}}=32.5 \mathrm{LE} /\right.$ windrow $)$, and the cost per cubic meter is $\left(\mathrm{C}_{\mathrm{v}}=7.2 \mathrm{LE} / \mathrm{m}^{3}\right)$. Within the duration of the pile, it was turned nine times from the $40^{\text {th }}$ day using the loader for establishing the pile, so it takes ten times to cost 325LE in total.

The naturally, and the passively aerated composting piles used the frontend loader to establish the piles. Then the cost of each pile was 32.5LE.That makes the naturally and passively aerated more economical than the agitation method.

\section{CONCLUSION:}

In this study the passively aerated (PA) static piling (with corn stalks inserted) was economically, and technically the best method. It had the best temperature regime and good chemical analysis. After that came the Agitation method (Agi) technically only, and at last the naturally aerated (NA) static pile method. The economical comparison showed that the Agitation method was most expensive - 325LE -, and that refers to the machine expenses which do not suit the small-scale composting. The naturally and passively aerated static piles were equal in expenses 32.5LE - . Passive aeration of piles, using corn stalks as air conducts are recommended over naturally aerated and turning agitation methods for small and moderate scale composting piles. This choice is due to better temperature regime and resulting chemical composition of compost.

\section{REFERENCES:}

Agnew, J.M., and J.J. Leonard, 2003. The physical properties of compost. Compost Science \& Utilization, 11(3): 238-264. 
Awady, M. N., M. M. Mostafa, A. M. El Gendy, and M. M. Hegazi, 2006, Introduction to Agricultural Engineering, $3^{\text {rd }} \cdot \mathrm{ch}$. on "Management of Agricultural Mechanization" by M. N. Awady, Col. Ag., A.S. Univ.:36-38 (In Arabic).

Hanna website: access date Jan 2008 www.hannacan.com .

Haug, R.T., 1993. The practical handbook of compost engineering. Lewis Pub.:717p.

Rynke, R., 1992. On farm composting handbook. NRAES-54 Ithaca, N.Y., Northeast Reg. Ag. Eng. Serv.:186p.

Sartaj, M., L. Fernandes, N. K. Patni.,1997 Performance of forced, passive, and natural aeration methods for composting manure slurries. Trans. ASAE, 40: 457-463.

Seki, H., 2002. A new deterministic model for forced aeration composting processes with the batch operation. Trans. ASAE, 45: 1239-1250.

الملخص العربي

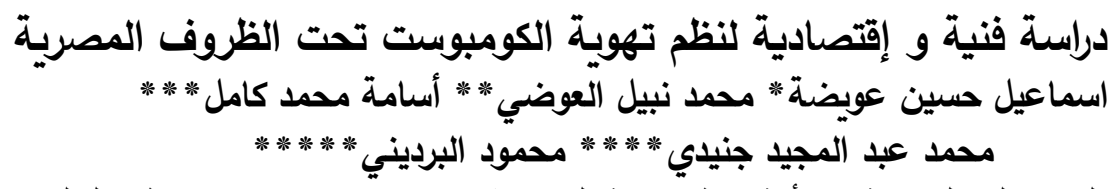

يهدف هذا البحث إلى المقارنة بين أكثر نظم خدمة الكمير شيو عالي في مصر و هي : نظام التقليب , نظام التهوية الطبيعية, مع اضافة نظام آخر يعتبر تطوير لنظام التهوية الطبيعية, و هو هو نظام

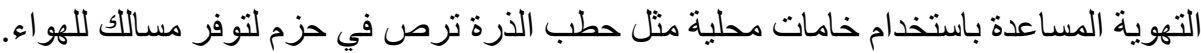

أولا: نظام التهوية الطيعية (Naturally aerated static piles)

تم استخدام هذا النظام كتجربة مقارنة حيث انه لم يعامل بمعاملات التهوية او التقليب، و يعتبر هذا النظام أساس كل نظم التكمير المفتوحة، و تعتبر النظم الأخرى مجرد مكملات. فالتهوية

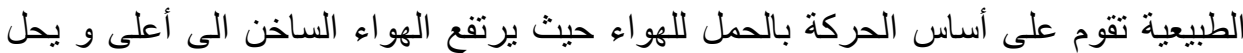
محله الهواء البارد. و بالرغم من سهولة النظام و عدم الحاجة إلى عمالة أو تقليب, إلا أن الن هذا النا النظام غير منتشر في مصر خصوصا لبعض البر المو اد الخام التى تأخذ وقتا طويلا في التحلل كقش التش

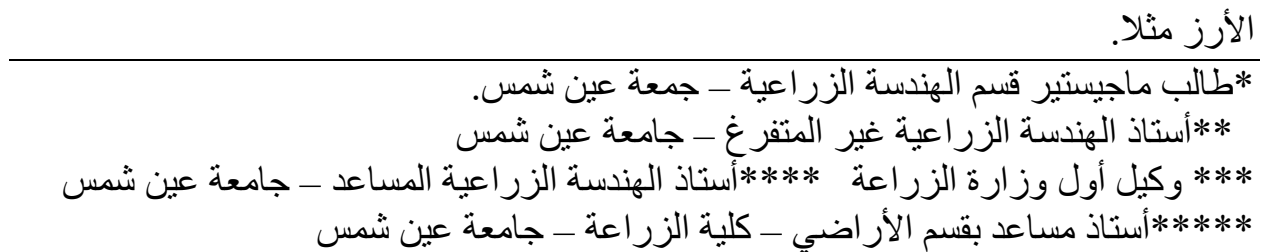
ثانيا: نظام التهوية المساعدة(Passively aerated static piles)؛ 


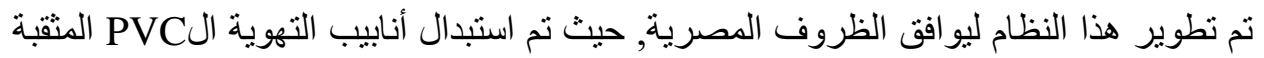

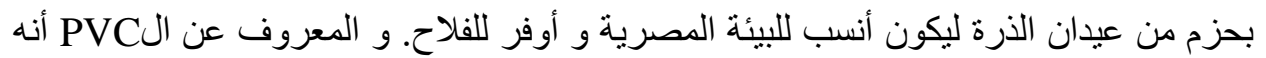

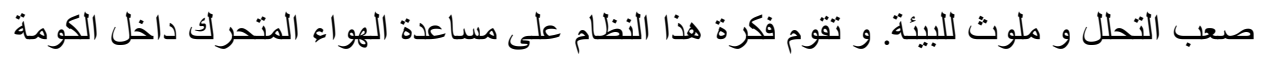

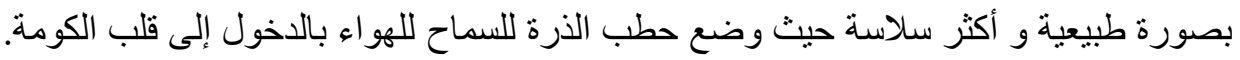

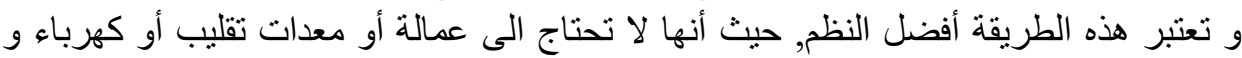
تقوم بإدخال الهو اء إلى قلب الكومة بدون تبريد.

\section{ثالثا: نظام التقليب(Turning agitation):}

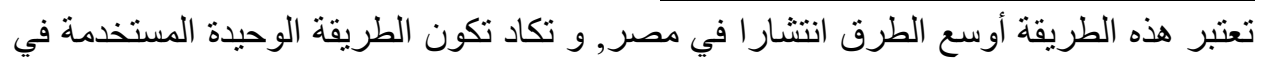

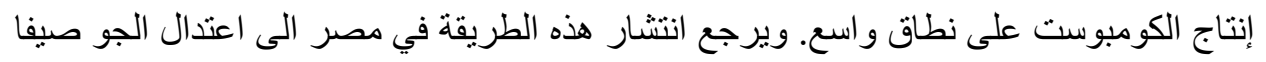

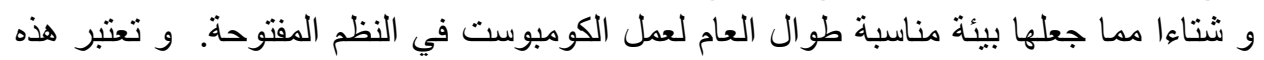

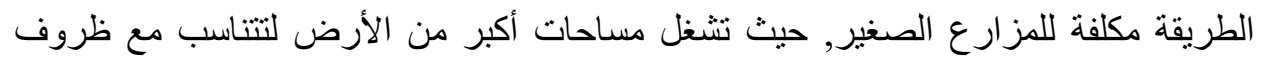

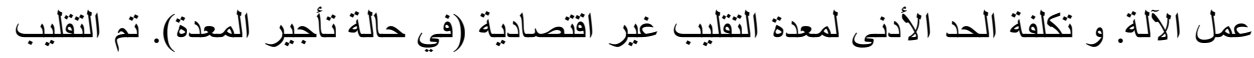

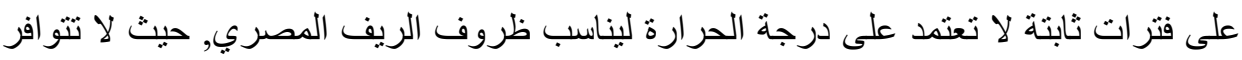

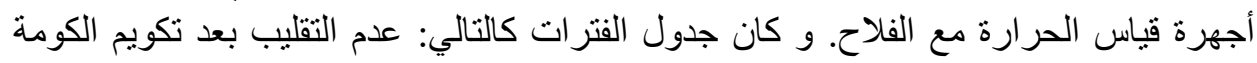

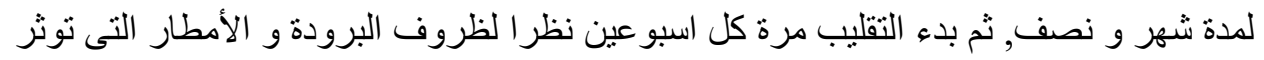
على نشاط الكومة مع زيادة التقليب.

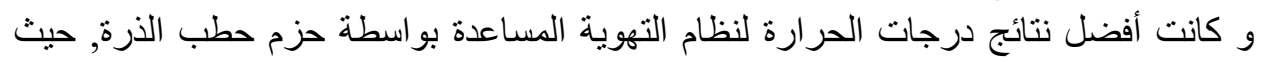

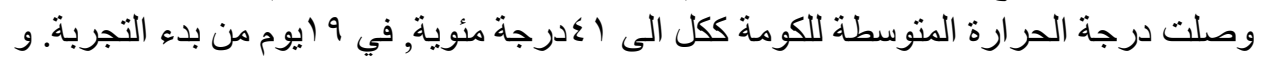

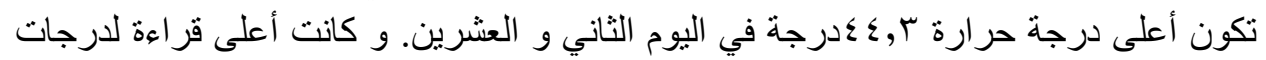

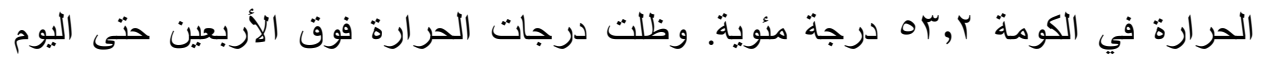

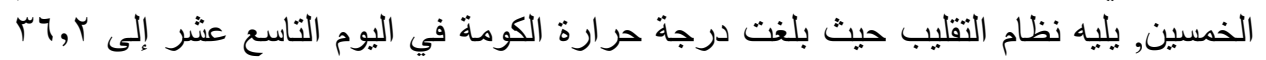

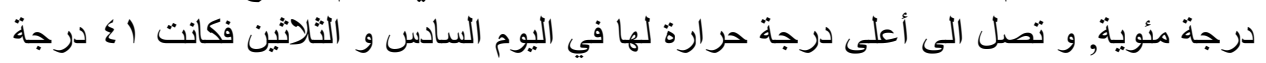

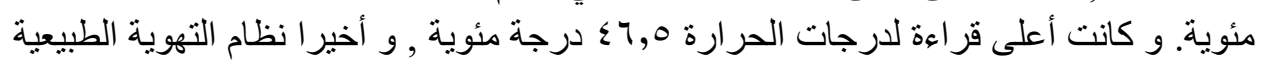

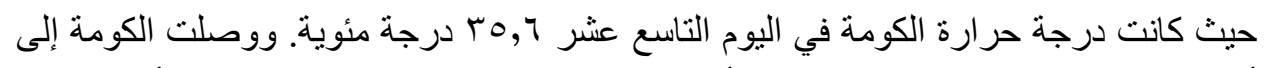

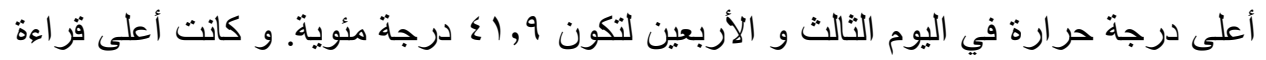

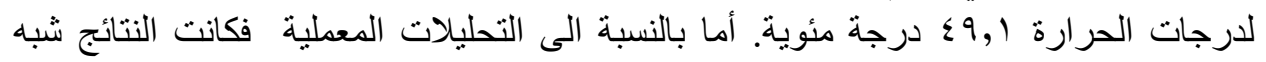

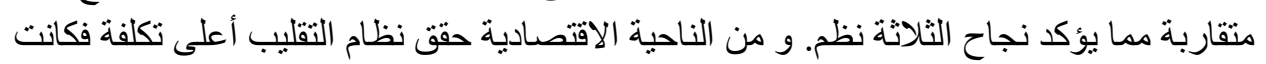

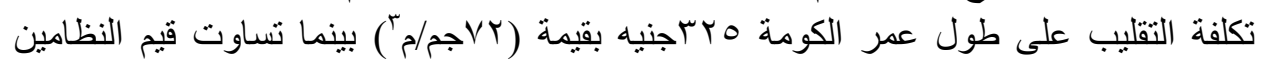

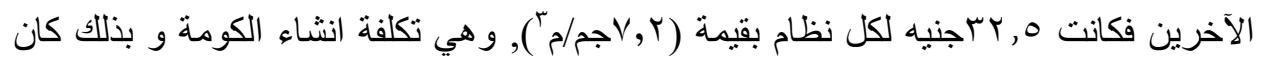

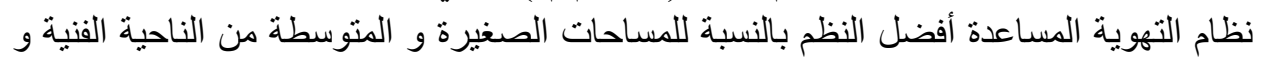



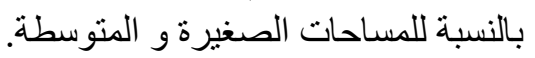






Elevation
$5 \mathrm{~cm}$ rice straw base

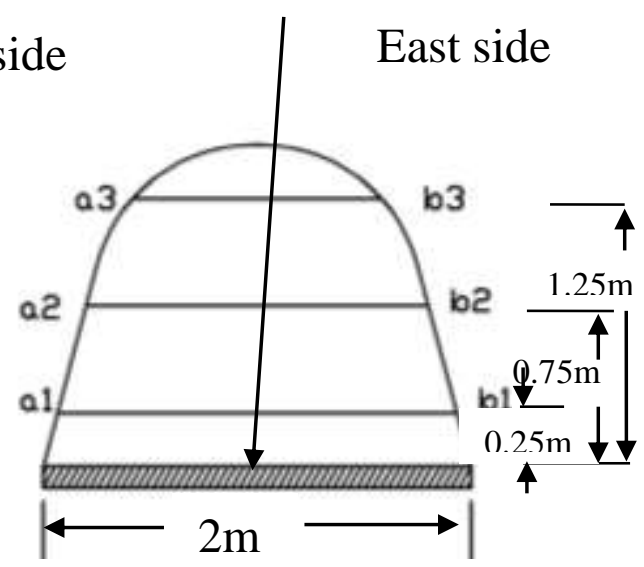

Side view

Fig 1: Natural aerated, and Agitation pile dimensions

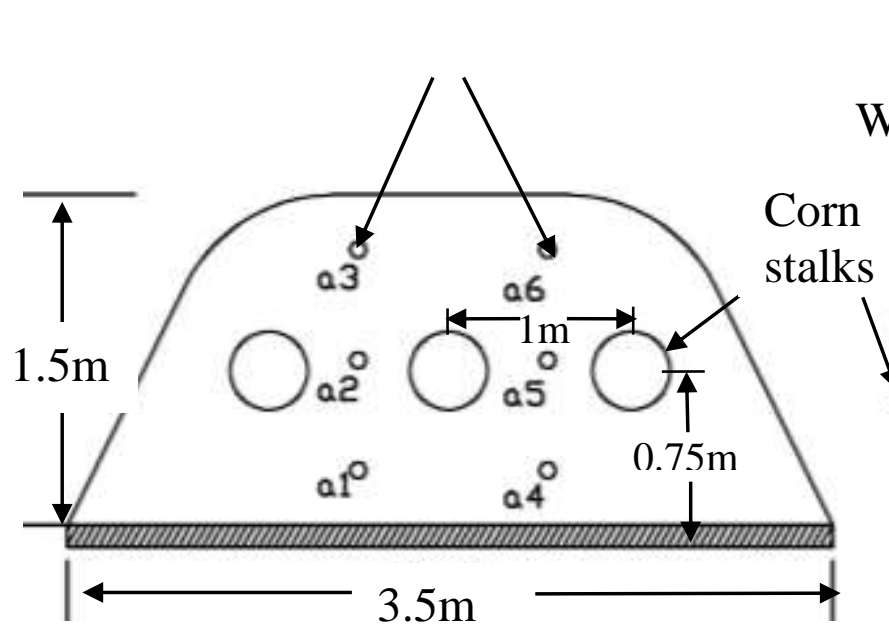

Elevation
$5 \mathrm{~cm}$ rice straw

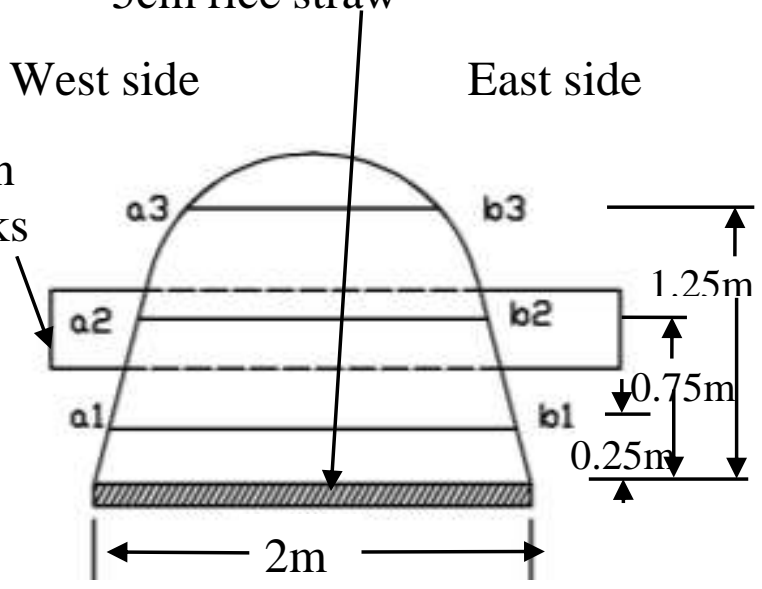

Side view

Fig 2: Passive aerated static pile dimensions. 


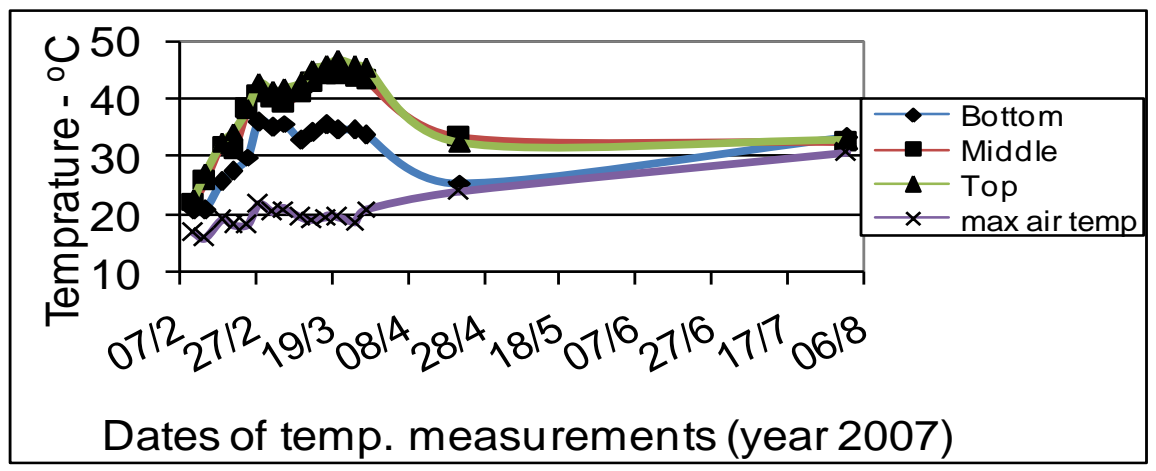

a) The temperature difference between layers in naturally aerated system.

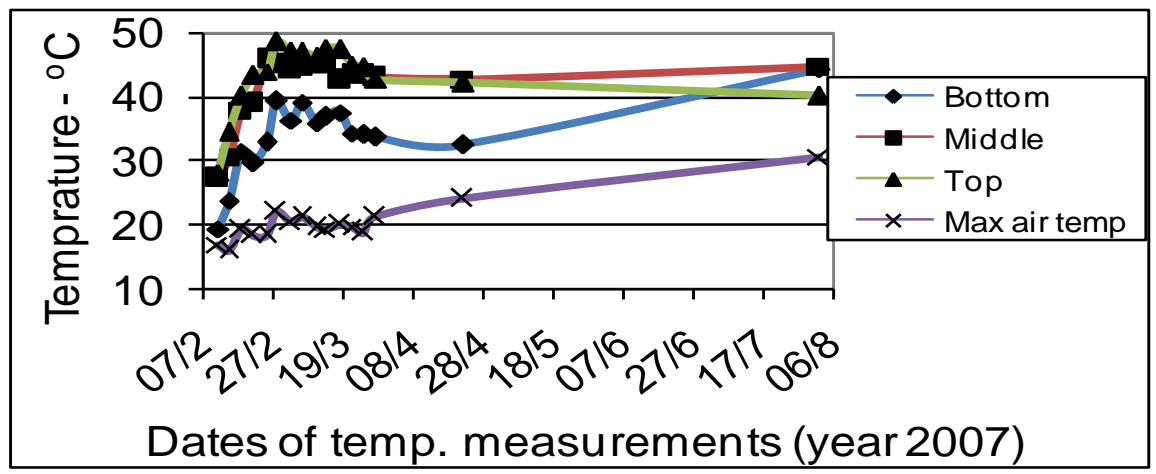

b) The temperature difference between layers in passively aerated system.

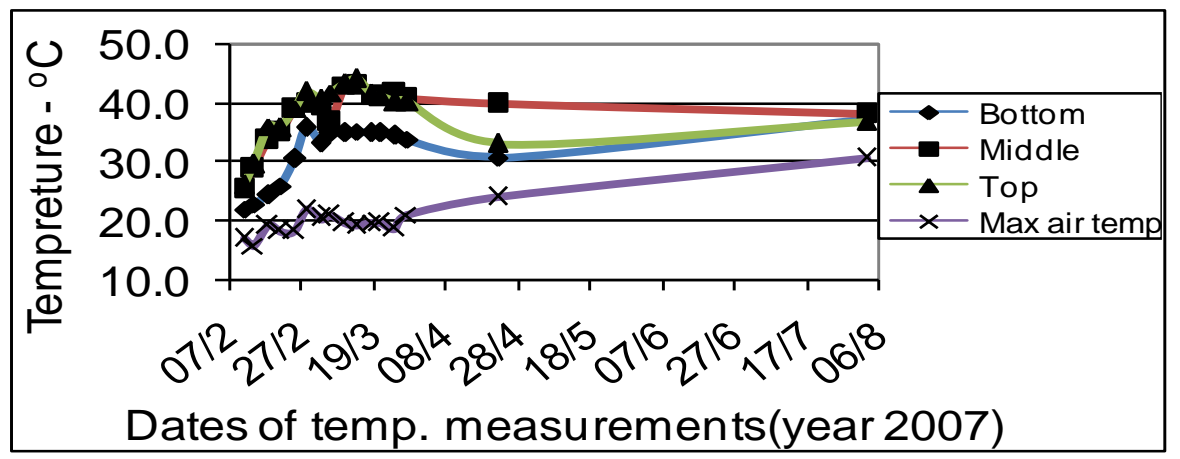

c) The temperature difference between layers in agitation system.

Fig 3: The temperature difference between layers in composting piles. 


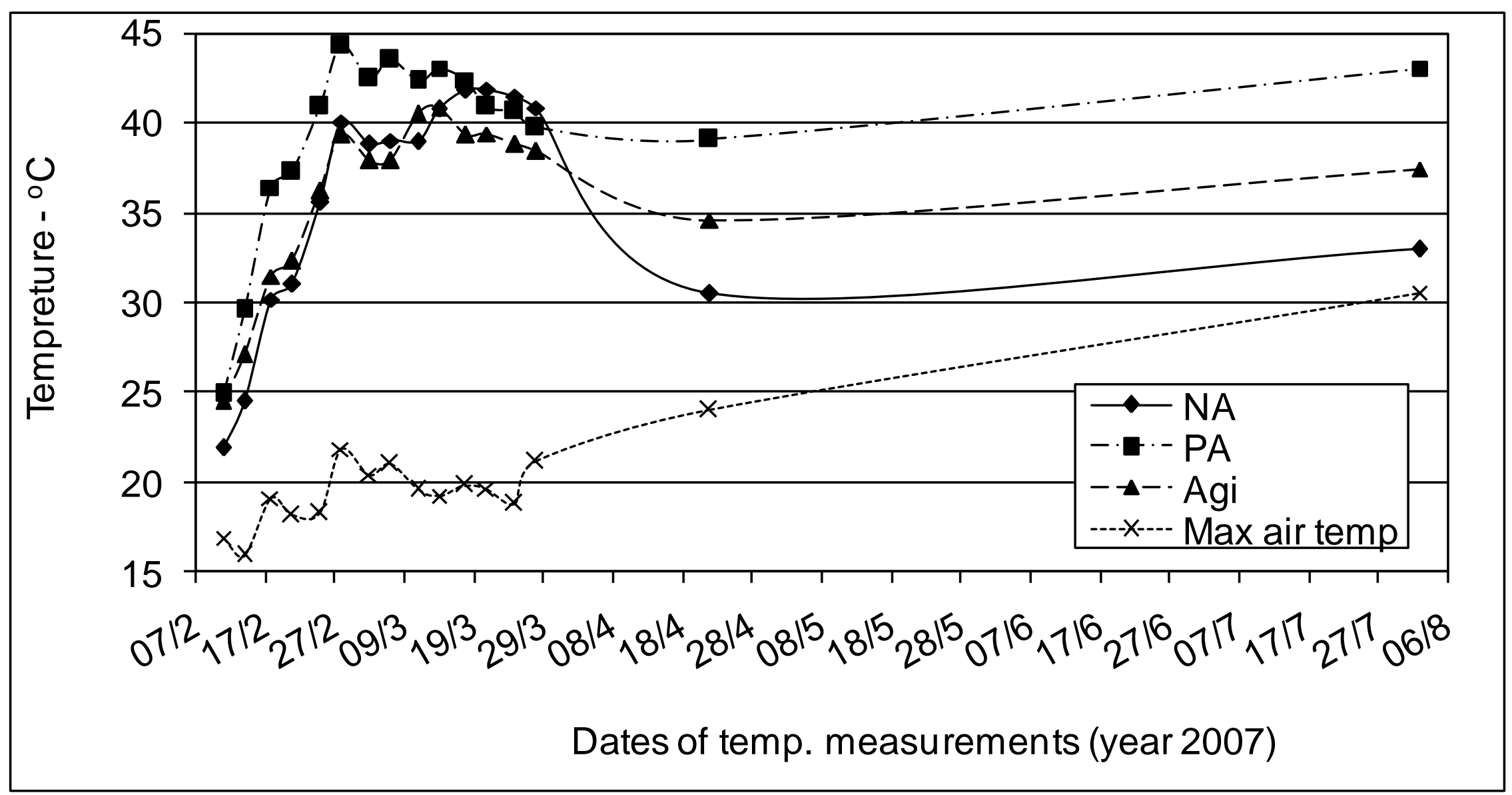

Fig 4: Temperature difference between composting methods and the air temperature average. 